\title{
EFFECT OF INJECTOR TYPES, IRRIGATION AND NITROGEN TREATMENTS ON EMITTERS CLOGGING
}

\section{El-Gindy $^{1}$ A. M, M.Y.Tayel ${ }^{2}$, K.F.El-Bagoury ${ }^{3}$, and Kh.A. .Sabreen ${ }^{4}$}

\begin{abstract}
Several problems are associated with drip irrigation system. Clogging of emitters appears to be one of the aimed most annoying problems related to drip irrigation. This research aimed to study the effect of injector types, irrigation requirements and nitrogen treatments on drippers clogging. To attain this target, three types of fertilizer injectors were investigated: bybass pressurized mixing tank $\left(J_{1}\right)$, venture $\left(J_{2}\right)$, and positive displacement pump (J3). Three irrigation treatments were used $50\left(I_{1}\right), 75\left(I_{2}\right)$, and 100 (I3) \% of ETc, and three levels of $\mathrm{N}$ - fertilizer $\left(\mathrm{NH}_{4}\right)_{2} \mathrm{SO}_{4}$ namely $60\left(\mathrm{~N}_{1}\right)$, $90\left(N_{2}\right)$, and $120\left(N_{3}\right) \mathrm{kg} / \mathrm{fed}$. The emitter clogging percentage was measured for the drip irrigation system at the beginning and the end of garlic growing season 2006 / 2007. According to clogging percent, the used injectors were arranged in the ascending order: $J_{3}<J_{2}<J_{1}$. Differences in clogging percent among the used injectors were significant at the 5\% level. Emitter clogging increased with increasing nitrogen application, and decreasing the irrigation rate. The maximum and minimum values of clogging percent were $(17.79,22.8 ; 27.9)$ and $(13.24$, $15.81 ; 18.9)$ under the condition of $\left(J_{3}, J_{2} ; J_{1}\right),\left(I_{1} \times N_{3}\right)$ and $\left(I_{3} \times N_{1}\right)$, respectively.
\end{abstract}

Keywords: Emitters clogging, Irrigation and $N$ levels, Injectors type, Egypt.

\section{INTRODUCTION}

( everal problems are associated with drip irrigation system. According to De Troch (1988), the most severe is the clogging of system components. Clogging of drippers is a major concern in drip irrigation systems.

1. Prof. of Agric. Eng., Faculty of Agriculture, Ain Shams University

2. Prof. of Soil Physics, and Water Relations, Field Irrigation Dept., NRC

3. Lecturer of Agric. Eng., Faculty of Agriculture, Ain Shams University

4. Assistant researcher, Water Relations and Field Irrigation Dept., NRC 
Buks et al (1977) stated that although drip irrigation has many advantages, it also has some limitations. Emitters clogging are the most common one. In (1979) they added that irrigation water quality affected the degree of emitters clogging. Dasberg and Bresler (1986) stated, complete or partial blocking of drippers reduces the application uniformity of both water and fertilizers and negatively affects plant growth. Drip irrigation systems have very slow flow rates and extreme small passages for water. These passages are easily clogged by three major categories of clogging agents: physical, chemical and biological. Two or more of these clogging categories may occur at the same time (Bucks and Nakayame, 1984, and De Troch, 1988).

Physical clogging is caused by inorganic and /or organic suspended particles in irrigation water, such as soil particles (clay, silt and sand) or planktonic organisms. These suspended particles can plug the narrow pathways of water within the drippers and their small openings. Pillsbury and Degan (1975) stated that these suspended particles can be removed by screening. They added that the small the pathways of water within the drippers and their openings, the finer the screen required. Media and cartridge filters and centrifugal separators are the main types of filters in addition to settling basins are used with drip irrigation system to get rid of these particles (De Troch, 1988).

Chemical precipitation, the second case of drippers clogging is caused by the deposition of salts and/or ions inside the drippers. Hills et al (1989) mentioned that carbonate precipitation is the most common type of chemical clogging in drip irrigation. Gilbert and Ford (1986) said that both dissolved iron and manganese (reduce form) may be oxidized into particulate forms that accumulate and block the drippers. In some cases, a combination of carbonate precipitation and some fertilizers are responsible for severe clogging of drip irrigation systems (Sagi, 1990). Sulfuric and hypochlorite acids are injected to reduce the $\mathrm{pH}$ of irrigation water and reduce the amount of chemical precipitates.

Biological clogging of drippers in drip irrigation system was reported to be due to the development of microbial slime in the lateral lines and in the drippers (Ford, 1984; Adin, 1987). Many drippers' malfunctions are caused by a combination of the physical, chemical and biological factors. 
Chlorine is used to control algae and bacterial slims. Bozkurt and Özekiei (2006) carried out a study to determine the effects of different fertigation practices on clogging in in-line emitters using Samandag region well water in Turkey. Their data show that different fertilizer treatments have significant effects on emitter clogging. Fertilizers containing both $\mathrm{Ca}^{++}$and $\mathrm{SO}^{--}$caused higher clogging compared with the others. Chang (2008) said that, as the flow slows down and/or the chemical background of the water changes, chemical precipitates and/or microbial flocs and slimes begin to form and grow, thus microirrigation emitter clogging occurs. Ravina et al. (1997) stated that, more clogged emitters were found at the end of the drip laterals than at the beginning (probably due to pressure head loss). This leads to non uniformity in the discharge rate of emitters within the system. Hebbar et al (2004) found that normal fertilizers generally tend to clog the emitters causing an uneven distribution of fertilizers.

The aim of this research was to study the effect of injector types, irrigation and nitrogen treatments on drippers clogging.

\section{MATERIALS AND METHODS}

Experiments were carried out at the Experimental Farm of the Faculty of Agriculture, Ain Shams University, at Shalaquan village, Kalubia Governorate.

\section{Irrigation water characteristics}

The source of irrigation water at experimental site is well water (the total depth of wall: $45 \mathrm{~m}$; water depth from ground surface: $4-5 \mathrm{~m}$; and diameter of well: 6"). Screen filter ( 2" /2" inlet, outlet diams.; $35 \mathrm{~m} 3 / \mathrm{h}$ discharge rate and filtration degree 120 mesh). A sample was taken from the irrigation water to be analyzed. Table (1) shows the results of irrigation water analysis.

\section{Fertilizer Injectors}

- Two main injection techniques were tested: the ordinary closed tank; and the pump. Both techniques were run by pressure difference in the irrigation system. The injector types were mainly by-bas-pressure mixing tank, venturi type and positive displacement pumps. 
Table (1): Some physical and chemical analysis

of the irrigation water at Shalaqan.

physical analysis

Suspended solid (ppm) 5-10

chemical analysis

pH

EC dS/m

0.85

Soluble Cations, meq/L:

$\begin{array}{ll}\mathbf{C a}^{++} & 1.72 \\ \mathbf{M g}^{++} & 0.85 \\ \mathrm{Na}^{+} & 4.78 \\ \mathbf{K}^{+} & 0.85\end{array}$

Soluble Anions, meq/L:

$\mathrm{HCO}^{-}$

$\mathrm{SO}_{4}^{--}$

0.14

$\mathrm{Cl}^{-}$

SAR

Under the field operating conditions, the different types of injectors were connected to a sub-main line $110 \mathrm{~mm}$ diameter by a by-bass arrangement. The injected fertilizer was a solution of ammonium sulphate $\left(\mathrm{NH}_{4}\right)_{2} \mathrm{SO}_{4}(21 \% \mathrm{~N})$ during fertigation time 2 hours from irrigation time 3 hours at two intervals. These amounts of fertilizers were divided into 20 doses and applied injecting with irrigation water during the growing season.

a. By-bass pressurized mixing tank $\left(\mathrm{J}_{1}\right)$ :

By-bass pressurized mixing tank is a cylindrical, inside epoxy coated, pressurized metal tank, resistant to the system's pressure, and connected as a by-bass to the main line. Tank dimensions were $40 \mathrm{~cm}$ in diameter and $160 \mathrm{~cm}$ in height (total volume $=200$ liters). The tank connected to submain line and controlled by $3 / 4$ " valves at the inlet and outlet. The flow rate of the solution is monitored by a flow meter installed on the by-bass pressurized mixing tank.

b. Venturi Injector $\left(\mathrm{J}_{2}\right)$ :

A venturi injector is a tapered constriction which operates on the principle that a pressure drop accompanies the increase in velocity of the water as it passes through the constriction. 
It was installed on a by-bass arrangement placed on an open container contained the fertilizer solution. The injector is constructed of a PE tube 3/4" in diameter. The venturi was devised by regulator valve which creates a differential pressure, thereby, allowing the injector to produce a vacuum.

\section{c. Positive displacement Injection Pump $\left(\mathrm{J}_{3}\right)$ :}

This type of injector consists of a mounting bag, by-bass control knob, dosage positive displacement and suction tube fitting and hose one inch to connect the inlet and outlet of the pump to fertilizer tank end irrigation system respectively, and valves. The dosage and discharge of completely soluble fertilizer can be adjusted by the dosage positive displacement. Positive displacement injection pump is used to inject completely dissolved chemicals through the irrigation network with maximum rate of $150 \mathrm{l} / \mathrm{m}$. Flow rate of this type ranges from $4.5 \mathrm{~m}^{3} / \mathrm{h}$ (maximum) at $7 \mathrm{bar}$ to $19 \mathrm{l} / \mathrm{h}$ (minimum) at 0.34 bar working pressure. The dosage volume spacers will be exposed. The more rings on the shaft the higher is the dosage rate. Actual injection rate will vary slightly depending on water flow rate.

\section{Experiment layout and treatments}

Field experiments were conducted in growing seasons 2006 / 2007 in split split plot design with three replications combined and three types of injectors. Both super phosphate $\left(15.5 \% \mathrm{P}_{2} \mathrm{O}_{5}\right)$ and potassium sulfate $(48 \%$ $\mathrm{K}_{2} \mathrm{O}$ ) were added at the rate of $100 \mathrm{~kg} / \mathrm{fed}$., by using traditional method of fertilization (broadcasting). This amount was divided into two doses $\left(1^{\text {st }}\right.$ during soil preparation and $2^{\text {nd }}$ after month from planting date). Chinese garlic variety (Allium sativum) was planted at the second week of September. The main plots were devoted to irrigation treatment $(33 \mathrm{~m} \times$ $7.2 \mathrm{~m}$ ). Three irrigation requirement treatments were 50,75 , and $100 \%$ of $\mathrm{ET}_{\mathrm{c}}$ ( i. e. 1423,2134 and $2846 \mathrm{~m}^{3} / \mathrm{fed} / \mathrm{season}$ ). On the other hand, $\mathrm{N}$ fertilizer treatments occupied the sub-plots $(33 \mathrm{~m} \times 2.4 \mathrm{~m})$. Three levels of $\mathrm{N}$-fertilizer namely $60,90,120 \mathrm{Kg} \mathrm{N} /$ fed were used. The levels of $\mathrm{N}$ fertilization were respectively 50,75, and $100 \%$ of the recommended dosage by Ministry of Agriculture and Land Reclamation. Since three methods for fertilizer application (by-bass fertilizer tank, venturi; piston pump) were used, the layout mentioned above was repeated three times. Garlic crop was drip irrigated every two days . It was harvested at the last week of April (i.e. growing season lasted 165 days).Treatments where: 


$$
\begin{array}{ll}
\mathbf{J}_{1} & =\text { By-Bass Pressurized Mixing Tank } \\
\mathbf{J}_{2} & =\text { Venturi } \\
\mathbf{J}_{3} & =\text { Positive Displacement Pump } \\
\mathbf{I}_{1} & =100 \% \text { of ET } \\
\mathbf{I}_{2} & =75 \% \text { of } \mathrm{ET}_{\mathrm{c}} \\
\mathbf{I}_{3} & =50 \% \text { of ET } \\
\mathbf{N}_{1} & =120 \mathrm{~kg} \mathrm{~N} / \mathrm{fed} \\
\mathbf{N}_{2} & =90 \mathrm{~kg} \mathrm{~N} / \mathrm{fed} \\
\mathbf{N}_{3} & =60 \mathrm{~kg} \mathrm{~N} / \mathrm{fed}
\end{array}
$$

\section{Emitters clogging}

The flow cross section in a long-path emitter is $0.7 \mathrm{~mm}$ for discharge 4 $1 / \mathrm{h}$. The emitter is considered laminar-flow-type $\left(\mathrm{N}_{\mathrm{R}}<2000\right)$ (James, 1998). To estimate the emitter flow rate cans and a stopwatch were used. Nine emitters from each lateral had been chosen to be evaluated by calculating their clogging ratio at the beginning and at the end of the growing season. Three emitters at the beginning, three at middle and three at the end of the lateral were tested for flow rate.

Clogging ratio was calculated after El-Berry et al ( 2003) using the following equations:

$\mathrm{E}=\mathrm{q}_{\mathrm{u}} / \mathrm{q}_{\mathrm{n}} \times 100$

$\mathrm{CR}=(1-\mathrm{E}) \times 100$

where:

$\mathrm{E} \quad=$ the emitter discharge efficiency,

$\mathrm{q}_{\mathrm{u}}=$ emitter discharge, at the end of the growing season

$\mathrm{q}_{\mathrm{n}} \quad=$ emitter discharge, at the beginning of the growing season

$\mathrm{CR}=$ the emitter clogging ratio,

\section{RESULTS AND DISCUSSION}

\section{Emitters clogging}

Data of emitters clogging are given in Tables $(2 ; 3)$ and Figs. $(1,2 ; 3)$. According to clogging percent, the injectors used: by-bass pressurized mixing tank $\left(\mathrm{J}_{1}\right)$, venturi $\left(\mathrm{J}_{2}\right)$ and piston pump $\left(\mathrm{J}_{3}\right)$ could be arranged in the following ascending order: $\mathrm{J}_{3}<\mathrm{J}_{2}<\mathrm{J}_{1}$, regardless of both irrigation and nitrogen treatments. Differences in clogging percent among the 
injectors used are significant on the 5\% level. It is well know that increasing pressure within the drip irrigation system decreases clogging problem and vice versa. The check valve used with injector $J_{1}$ decreases the pressure within the irrigation system i.e. 0.1 bar $\leq \Delta \mathrm{P} \leq 0.7$ bar. Concerning injector $\left(\mathrm{J}_{2}\right)$, the contracted part increases irrigation water flow velocity on the expense of the pressure. This of course is attributed to the increase in friction loss. The $\Delta \mathrm{P}$ in operating pressure is $0.4 \mathrm{bar} \leq$ $\Delta \mathrm{P} \leq 1.4$ bar. With respect to injector $\left(\mathrm{J}_{3}\right)$, it injects $\mathrm{N}$-solution at pressure higher than that within the irrigation system. Therefore, if injector $\left(\mathrm{J}_{3}\right)$ does not increase the pressure within the irrigation system it will not decrease it. Also, the reciprocating movement of the piston within its cylinder in the pump can cause a good agitation and well string of the nitrogen solution. This will lead to reducing the percentage of clogging (Phocaides, 2000). This is clear from the range of its operating pressure 1.0 bar $\leq \Delta \mathrm{P} \leq 2.5$ bar. Thus, the injectors used could be put in the following ascending order according to the range of their operating pressure: $\mathrm{J}_{1}<\mathrm{J}_{2}<\mathrm{J}_{3}$. This order is the opposite of the above mentioned one representing clogging percent. Data on hand indicate that the clogging problem could be relieved with increasing the irrigation level.

According to clogging percent, irrigation treatments could be written in the following ascending order: $\mathrm{I}_{3}\left(100 \%\right.$ of $\left.\mathrm{ET}_{\mathrm{c}}\right)<\mathrm{I}_{2}\left(75 \%\right.$ of $\left.\mathrm{ET}_{\mathrm{c}}\right)<\mathrm{I}_{1}$ $\left(50 \%\right.$ of $\left.\mathrm{ET}_{\mathrm{c}}\right)$. Difference in clogging percent between any two irrigation treatments is significant at the $5 \%$ level. This is due to that emitters are more flushed in the opposite of the sequence mentioned before. The obtained data show that increasing the amount of the applied nitrogen fertilizer $\left(\mathrm{NH}_{4}\right)_{2} \mathrm{SO}_{4}$ from $60\left(\mathrm{~N}_{1}\right)$ to $120 \mathrm{~kg} / \mathrm{fed}$. $\left(\mathrm{N}_{3}\right)$ increased the clogging percent under all irrigation treatments and the three injectors used. A cording to clogging percent, the following ascending order illustrates the role of nitrogen treatments: $\mathrm{N}_{1}<\mathrm{N}_{2}<\mathrm{N}_{3}$

This could be explained on the basis that increasing nitrogen content will increase the amount of Calcium and magnesium that will precipitate within the emitters and in their narrow openings after water evaporation, especially in the form of $\mathrm{CO}_{3}{ }^{-}$and $\mathrm{SO}_{4}^{--}$. In conclusion, it is obvious that the problem of emitter clogging increased with increasing nitrogen $\left(\mathrm{NH}_{4}\right)_{2} \mathrm{SO}_{4}$ application, and decreasing the irrigation rate. The maximum 
and minimum values of clogging percent are $(17.79,22.8 ; 27.9)$ and $(13.24,15.81 ; 18.9)$ under the condition of $\left(\mathrm{J}_{3}, \mathrm{~J}_{2} ; \mathrm{J}_{1}\right),\left(\mathrm{I}_{1} \times \mathrm{N}_{3}\right)$ and $\left(\mathrm{I}_{3} \times\right.$ $\mathrm{N}_{1}$ ), respectively.

According to clogging percent injectors used could be written in the following ascending order $\mathrm{J}_{3}<\mathrm{J}_{2}<\mathrm{J}_{1}$. The results obtained agree well with those of Sagi (1990).

\section{First interaction (Table 3)}

\section{a. Injector $\times$ Irrigation}

The effect of injector types versus irrigation treatments on clogging per cent was significant at the $5 \%$ level. The maximum clogging per cent (27.03) and the minimum one (14.39) were obtained in the interactions: $\mathrm{J}_{1} \times \mathrm{I}_{1}$ and $\mathrm{J}_{3} \times \mathrm{I}_{3}$, respectively.

\section{b. Injector $\times \mathrm{N}$-treatments}

This interaction has a significant effect on clogging per cent at the 5\% level. The maximum clogging percent (23.16) and the minimum one (14.55) took place in the interactions $\mathrm{J}_{1} \times \mathrm{N}_{3}$ and $\mathrm{J}_{3} \times \mathrm{N}_{1}$, respectively.

\section{c. Irrigation $\times \mathrm{N}$-treatments:}

This interaction has a significant effect on the problem of emitter clogging per cent on the 5\% level with the exception of the cases: $\mathrm{I}_{3} \times \mathrm{N}_{3}$ and $\mathrm{I}_{2} \times \mathrm{N}_{2}$. The maximum clogging percent (22.83) and the minimum one (15.98) can be noticed in the two interactions: $I_{1} \times N_{3}$ and $I_{3} \times N_{1}$, respectively.

\section{Second Interaction (Table 3)}

\section{a. $\mathbf{J}_{1} \times \mathbf{I} \times \mathbf{N}$}

This interaction led to significant effect on clogging per cent on the 5\% level. The highest clogging percent (27.9) and the lowest one (18.9) are due to the two interactions: $\mathrm{J}_{1} \times \mathrm{I}_{1} \times \mathrm{N}_{3}$ and $\mathrm{J}_{1} \times \mathrm{I}_{3} \times \mathrm{N}_{1}$, respectively.

\section{b. $\mathbf{J}_{2} \times \mathbf{I} \times \mathbf{N}$}

The interaction mentioned above caused a significant difference in clogging percent at the 5\% level. The maximum clogging per cent (22.8) and the minimum one (15.81) are found in the two interactions: $J_{2} \times I_{1} \times$ $\mathrm{N}_{3}$ and $\mathrm{J}_{2} \times \mathrm{I}_{3} \times \mathrm{N}_{1}$, respectively.

\section{c. $\mathbf{J}_{3} \times \mathbf{I} \times \mathbf{N}$}

It has a significant effect on clogging per cent at the $5 \%$ level. The highest clogging per cent (17.79) and the lowest one (13.24) are caused by the two interactions: $\mathrm{J}_{3} \times \mathrm{I}_{1} \times \mathrm{N}_{3}$ and $\mathrm{J}_{3} \times \mathrm{I}_{3} \times \mathrm{N}_{1}$, respectively. 

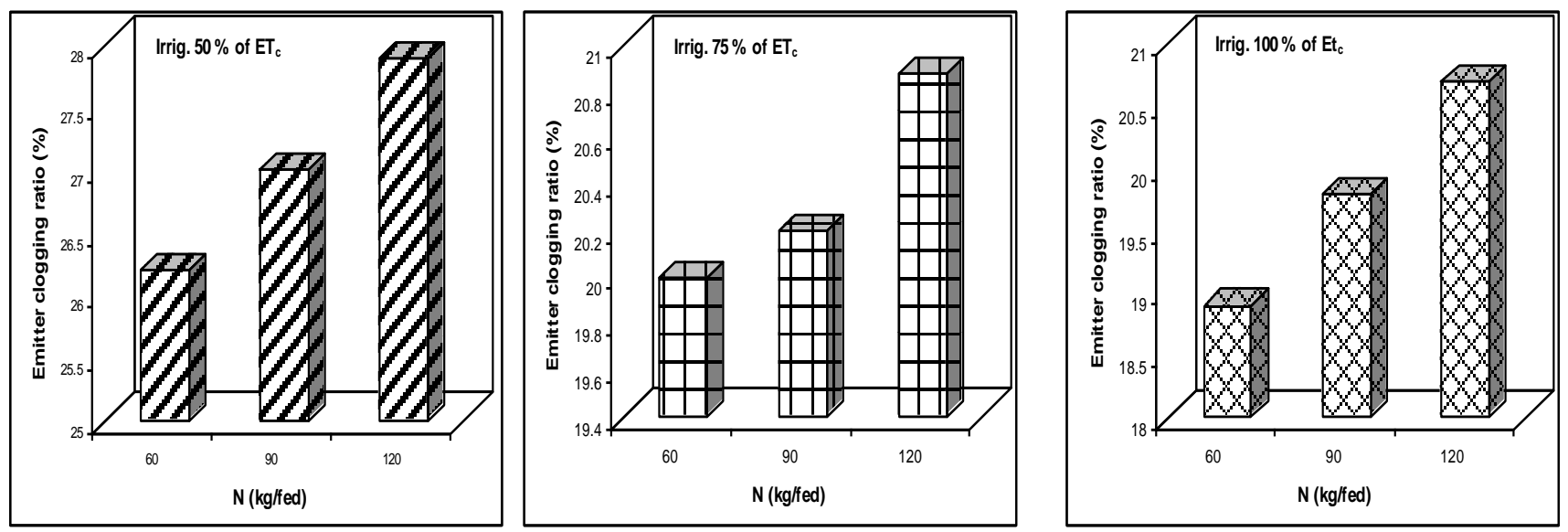

Figure (1): Effect of irrigation and fertilization treatments on emitter clogging percent (fertilizer tank).
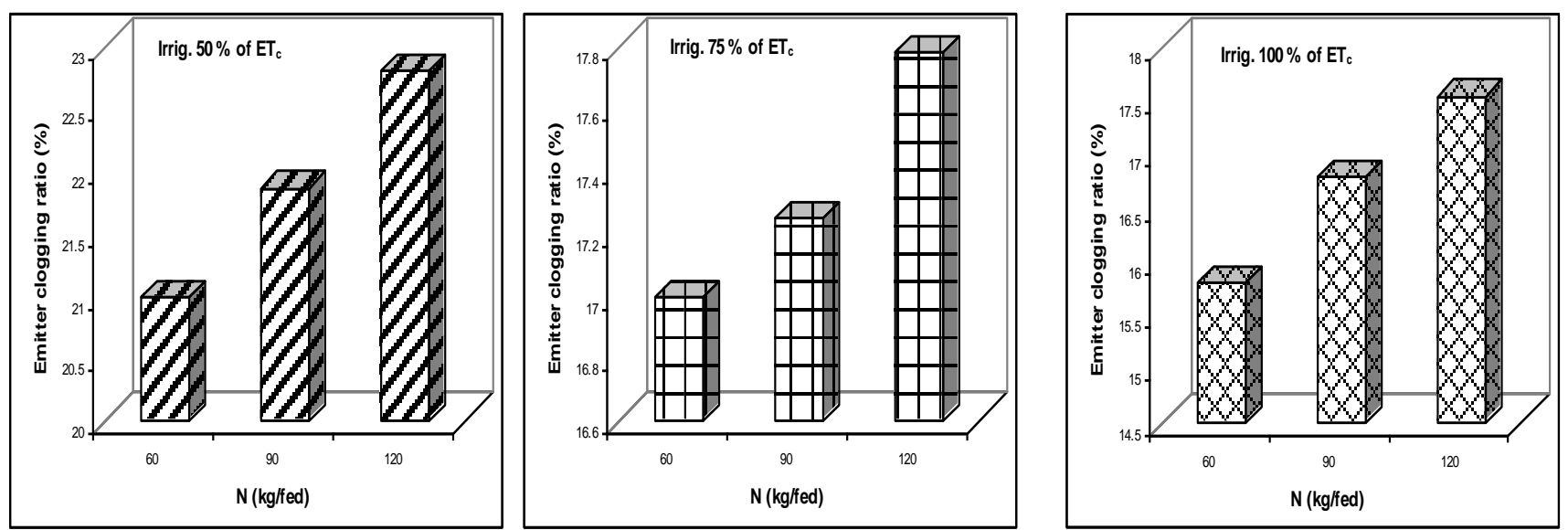

Figure (2): Effect of irrigation and fertilization treatments on emitter clogging percent (venturi ). 

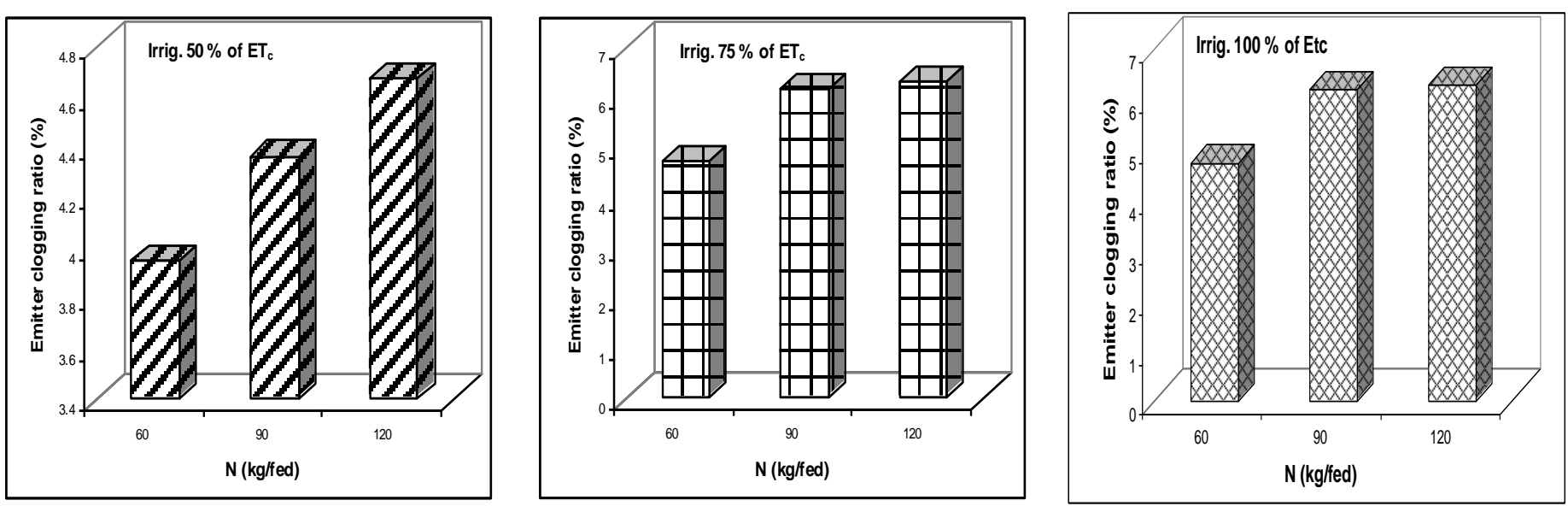

Figure (3): Effect of irrigation and fertilization treatments on emitter clogging percent (piston pump).

Table (2): Main effect of injector, irrigation and nitrogen fertilizer on clogging $\%$.

\begin{tabular}{|c|c|c|c|c|c|c|c|c|}
\hline Treatments & \multicolumn{2}{|c|}{ Clogging percent } & \multirow{2}{*}{$\frac{\text { Treatments }}{100 \% \text { of } \mathrm{ET}_{\mathrm{c}}}$} & \multicolumn{2}{|c|}{ Clogging percent } & \multirow{2}{*}{$\frac{\text { Treatments }}{120 \mathrm{~kg} / \text { fed of } \mathrm{N} .}$} & \multicolumn{2}{|c|}{ Clogging percent } \\
\hline By-bass pressurized mixing tank & 22.400 & $a$ & & 16.970 & c & & 19.530 & a \\
\hline Venturi & 18.650 & b & $75 \%$ of $\mathrm{ET}_{\mathrm{c}}$ & 17.590 & $\mathrm{~b}$ & $90 \mathrm{~kg} /$ fed of $\mathrm{N}$. & 19.040 & $\mathrm{~b}$ \\
\hline Positive displacement pump & 15.580 & $\mathrm{c}$ & $50 \%$ of $\mathrm{ET}_{\mathrm{c}}$ & 22.070 & a & $60 \mathrm{~kg} / \mathrm{fed}$ of $\mathrm{N}$. & 18.060 & $\mathrm{c}$ \\
\hline
\end{tabular}


Table (3): First and second interaction among injector, irrigation and nitrogen fertilizer treatments on clogging $\%$.

\begin{tabular}{|c|c|c|c|c|c|}
\hline Treatments & Clogging & & Treatments & Clogging & $\%$ \\
\hline $\mathrm{J}_{1} \times \mathrm{I}_{3}$ & 19.800 & d & $\mathrm{J}_{1} \mathrm{XI}_{3} \mathrm{XN}_{3}$ & 20.700 & $\mathrm{~h}$ \\
\hline $\mathrm{J}_{1} \mathrm{XI}_{2}$ & 20.360 & $\mathrm{c}$ & $\mathrm{J}_{1} \mathrm{XI}_{3} \mathrm{XN}_{2}$ & 19.800 & $\mathrm{k}$ \\
\hline $\mathrm{J}_{1} \mathrm{XI}_{1}$ & 27.030 & $\mathrm{a}$ & $\mathrm{J}_{1} \mathrm{XI}_{3} \mathrm{XN}_{1}$ & 18.900 & 1 \\
\hline $\mathrm{J}_{2} \mathrm{XI}_{3}$ & 16.720 & g & $\mathrm{J}_{1} \mathrm{XI}_{2} \mathrm{XN}_{3}$ & 20.880 & $\mathrm{~g}$ \\
\hline $\mathrm{J}_{2} \mathrm{XI}_{2}$ & 17.340 & $\mathrm{e}$ & $\mathrm{J}_{1} \mathrm{XI}_{2} \times \mathrm{N}_{2}$ & 20.200 & $\mathrm{i}$ \\
\hline $\mathrm{J}_{2} \mathrm{XI}_{1}$ & 21.890 & $\mathrm{~b}$ & $\mathrm{~J}_{1} \mathrm{XI}_{2} \mathrm{XN}_{1}$ & 20.000 & $\mathrm{j}$ \\
\hline $\mathrm{J}_{3} \mathrm{XI}_{3}$ & 14.390 & $\mathrm{i}$ & $\mathrm{J}_{1} \mathrm{XI}_{1} \times \mathrm{N}_{3}$ & 27.900 & $\mathrm{a}$ \\
\hline $\mathrm{J}_{3} \mathrm{XI}_{2}$ & 15.060 & $\mathrm{~h}$ & $\mathrm{~J}_{1} \mathrm{XI}_{1} \mathrm{XN}_{2}$ & 27.000 & $\mathrm{~b}$ \\
\hline $\mathrm{J}_{3} \mathrm{XI}_{1}$ & 17.280 & $\mathrm{f}$ & $\mathrm{J}_{1} \times \mathrm{I}_{1} \times \mathrm{N}_{1}$ & 26.200 & $\mathrm{c}$ \\
\hline $\mathrm{J}_{1} \times \mathrm{N}_{3}$ & 23.160 & $\mathrm{a}$ & $\mathrm{J}_{2} \mathrm{XI}_{3} \mathrm{XN}_{3}$ & 17.550 & o \\
\hline $\mathrm{J}_{1} \mathrm{XN}_{2}$ & 22.330 & $\mathrm{~b}$ & $\mathrm{~J}_{2} \mathrm{XI}_{3} \mathrm{XN}_{2}$ & 16.800 & $\mathrm{r}$ \\
\hline $\mathrm{J}_{1} \mathrm{XN}_{1}$ & 21.700 & $\mathrm{c}$ & $\mathrm{J}_{2} \mathrm{XI}_{3} \mathrm{XN}_{1}$ & 15.810 & $\mathrm{u}$ \\
\hline $\mathrm{J}_{2} \mathrm{XN}_{3}$ & 19.380 & $\mathrm{~d}$ & $\mathrm{~J}_{2} \mathrm{XI}_{2} \mathrm{XN}_{3}$ & 17.780 & $\mathrm{~m}$ \\
\hline $\mathrm{J}_{2} \mathrm{XN}_{2}$ & 18.640 & $\mathrm{e}$ & $\mathrm{J}_{2} \mathrm{XI}_{2} \mathrm{XN}_{2}$ & 17.250 & $\mathrm{p}$ \\
\hline $\mathrm{J}_{2} \mathrm{XN}_{1}$ & 17.940 & $\mathrm{f}$ & $\mathrm{J}_{2} \mathrm{XI}_{2} \times \mathrm{N}_{1}$ & 17.000 & $q$ \\
\hline $\mathrm{J}_{3} \mathrm{XN}_{3}$ & 16.040 & $\mathrm{~h}$ & $\mathrm{~J}_{2} \mathrm{XI}_{1} \mathrm{XN}_{3}$ & 22.800 & $\mathrm{~d}$ \\
\hline $\mathrm{J}_{3} \mathrm{XN}_{2}$ & 16.150 & $\mathrm{~g}$ & $\mathrm{~J}_{2} \mathrm{XI}_{1} \mathrm{XN}_{2}$ & 21.870 & $\mathrm{e}$ \\
\hline $\mathrm{J}_{3} \times \mathrm{N}_{1}$ & 14.550 & $\mathrm{i}$ & $\mathrm{J}_{2} \mathrm{XI}_{1} \mathrm{XN}_{1}$ & 21.000 & $\mathrm{f}$ \\
\hline $\mathrm{I}_{3} \times \mathrm{N}_{3}$ & 17.780 & $\mathrm{e}$ & $\mathrm{J}_{3} \mathrm{XI}_{3} \mathrm{XN}_{3}$ & 15.100 & w \\
\hline $\mathrm{I}_{3} \mathrm{XN}_{2}$ & 17.150 & $\mathrm{f}$ & $\mathrm{J}_{3} \mathrm{XI}_{3} \mathrm{XN}_{2}$ & 14.840 & $\mathrm{x}$ \\
\hline $\mathrm{I}_{3} \mathrm{XN}_{1}$ & 15.980 & $\mathrm{~h}$ & $\mathrm{~J}_{3} \mathrm{XI}_{3} \mathrm{XN}_{1}$ & 13.240 & $\mathrm{z}$ \\
\hline $\mathrm{I}_{2} \mathrm{XN}_{3}$ & 17.960 & d & $\mathrm{J}_{3} \mathrm{XI}_{2} \mathrm{XN}_{3}$ & 15.230 & $\mathrm{v}$ \\
\hline $\mathrm{I}_{2} \mathrm{XN}_{2}$ & 17.770 & $\mathrm{e}$ & $\mathrm{J}_{3} \mathrm{XI}_{2} \mathrm{XN}_{2}$ & 15.870 & $\mathrm{t}$ \\
\hline $\mathrm{I}_{2} \mathrm{XN}_{1}$ & 17.030 & g & $\mathrm{J}_{3} \mathrm{XI}_{2} \mathrm{XN}_{1}$ & 14.090 & $\mathrm{y}$ \\
\hline $\mathrm{I}_{1} \times \mathrm{N}_{3}$ & 22.830 & $\mathrm{a}$ & $\mathrm{J}_{3} \mathrm{XI}_{1} \mathrm{XN}_{3}$ & 17.790 & $\mathrm{~m}$ \\
\hline $\mathrm{I}_{1} \times \mathrm{N}_{2}$ & 22.210 & $\mathrm{~b}$ & $\mathrm{~J}_{3} \mathrm{XI}_{1} \mathrm{XN}_{2}$ & 17.750 & $\mathrm{n}$ \\
\hline $\mathrm{I}_{1} \times \mathrm{N}_{1}$ & 21.170 & $\mathrm{c}$ & $\mathrm{J}_{3} \mathrm{XI}_{1} \mathrm{XN}_{1}$ & 16.300 & $\mathrm{~s}$ \\
\hline
\end{tabular}

Means with different letters within each column are significant at a $0.05 \%$ level. 


\section{CONCLUSION}

This research aimed to study the effect of injector types, irrigation treatments and nitrogen treatments on emitters clogging. To attain to this target, three types of fertilizer injectors were investigated: by-bass pressurized mixing tank $\left(\mathrm{J}_{1}\right)$, venturi $\left(\mathrm{J}_{2}\right)$, and positive displacement pump $\left(\mathrm{J}_{3}\right)$. Three irrigation treatments were used $50\left(\mathrm{I}_{1}\right), 75\left(\mathrm{I}_{2}\right)$, and $100\left(\mathrm{I}_{3}\right) \%$ of $\mathrm{ET}_{\mathrm{c}}$, and three levels of $\mathrm{N}$ - fertilizer namely $60\left(\mathrm{~N}_{1}\right), 90\left(\mathrm{~N}_{2}\right)$, and 120 $\left(\mathrm{N}_{3}\right) \mathrm{kg} / \mathrm{fed}$. The drip irrigation emitter clogging percentage was measured at the end of garlic growing season 2006 / 2007.

The results show that, emitter clogging increased with increasing nitrogen application, and decreasing the irrigation treatments. The maximum and minimum values of clogging percent are $(17.79,22.8 ; 27.9)$ and $(13.24$, $15.81 ; 18.9)$ under the condition of $\left(J_{3}, J_{2} ; J_{1}\right),\left(I_{1} \times N_{3}\right)$ and $\left(I_{3} \times N_{1}\right)$, respectively. According to clogging percent injectors, irrigation and nitrogen treatments used could be written in the following ascending orders $\mathrm{J}_{3}<\mathrm{J}_{2}<\mathrm{J}_{1}, \mathrm{I}_{3}<\mathrm{I}_{2}<\mathrm{I}_{1}$ and $\mathrm{N}_{1}<\mathrm{N}_{2}<\mathrm{N}_{3}$, respectively interactions: $\mathrm{J} \times \mathrm{I}, \mathrm{J} \times \mathrm{N}, \mathrm{I} \times \mathrm{N}$ and $\mathrm{J} \times \mathrm{I} \times \mathrm{N}$ have significant effects at the $5 \%$ level on the problem of emitter clogging percent .

\section{REFERENCES}

Adin, A., 1987. Clogging in irrigation system reusing pond effluent and its prevention. Water Sci. Technol. 19-23

Bozkurt, S. and B. Özekiei, 2006. The effects of fertigation managements on clogging of in in-line emitters. J.Apl. Sci. , 6 (15): 3026-3034.

Bucks, D.A., and F.S., Nakayama, 1984, Problems to avoid with Drip /Trickle irrigation systems, Proc. Amer. Soc. Civil Eng. Specially Conf. Irr. and Drainage Div., 24-84 .

Bucks, D.A., and F.S., Nakayama and R. G. Gilbert, 1977 . Clogging research on drip irrigation. Proceedings 4 th. Annual international Drip irrigation Associate Meeting, pp: 25-31

Bucks, D.A., and F.S., Nakayama and R. G. Gilbert, 1979. Trickle irrigation water quality and preventive maintenance. Agric. Water Manage.,2: 149-162.

Chang, C. A., 2008, Drip lines and emitters: chlorination for disinfection and prevention of clogging, 
$\underline{\text { http://www.informaworld.com/smpp/content } \sim \text { content=a792065664 } \mathrm{db}=\mathrm{al}}$ l jumptype

Dasberg, S., and E., Bresler, 1986, Drip irrigation manual. International irrigation information center, Publ. No. 9, Voleani Center, Bet Dagan, Israel, 61pp.

De Troch, F.,1988. Irrigation and drainage. Gent univ. Belgium.

El-Berry, A. M., G. A. Bakeer, and A. M. Al-Weshali. 2003. The effect of water quality and aperture size on clogging of emitters. http://afeid.montpellier.cemagref.fr/Mpl2003/AtelierTechno/Atelier Techno/Papier\%20Etier/N\%C2\%BO48\%20\%20EGYPTE_BM.pdf

Ford, H.W., 1984, The problem of emitter clogging and methods for control, Citrus Ind., 46-52 .

Gilbert, R. G., and H. W., Ford, 1986, Operational principles emitters clogging. In trickle irrigation for crop production, Eds. F.S. Nakayama and D.A. Bucks, New York: 42-163.

Hebbar, S. S., B. K. Ramachandrappa, H. V. Nanjappa and M. Prabhakar, 2004. Studies on NPK drip fertigation in field grown tomato(Lycopersicon esulentum Mill.) Eur. J. Agron., 21: 117-127.

Hills, D.J., F.M. Nawar, and P.M., Waller, 1989, Effect of chemical clogging on drip-tap irigation uniformity, Trans. ASAE, 32(4) 1202-1206.

James, L. G., 1988, Principles of farm irrigation system design, Johan Wiley and sons, 264- 268.

Phocaides A., 2000. Tecchnical handbook of Pressurized Irrigation Techniques, FAO, Rome: 145 - 149.

Pillsbury, A.F and A. Degan, 1975. Sprinkler irrigation.FAO,Agricultural Development Paper No. 88, Rome.

Ravina, I. E, P. Z. Sofer, A. Marcu, A. Shisha, G. Sagi, and Y. Lev. 1997. Control of clogging in drip irrigation with stored treated municipal sewage effluent. Agricultural Water Management, 33(23): 127-137.

Sagi, G., 1990, Water quality and clogging of irrigation systems in Israel in 1989, Water and Irrigation Bull. (in Hebrew), 280:57-61 . 


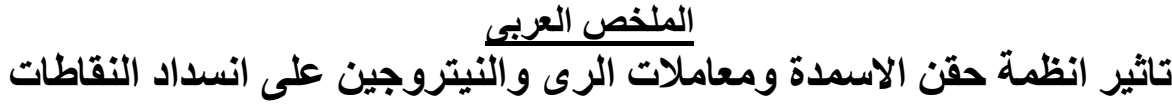 عبد الغتي الجندي ' ،محمد يوسف طايل ’ ، خالد فران الباجوري ' ،صابرين خليل احمد بيبارس2}

هنالك العديد من المشكلات المرتبطة بنظام الري بالتنقيط فيعتبر إنسداد النقاطات واحد من

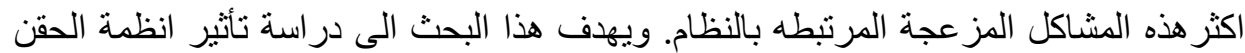

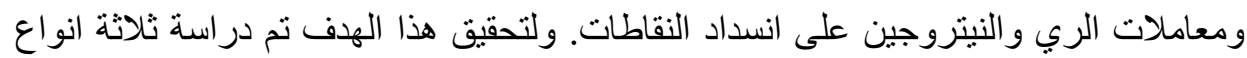

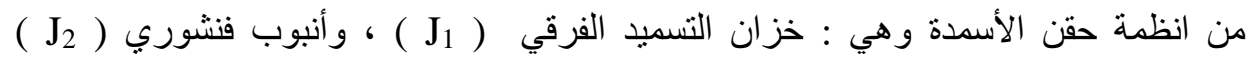

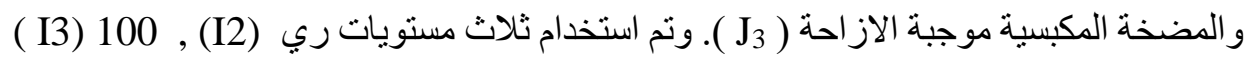

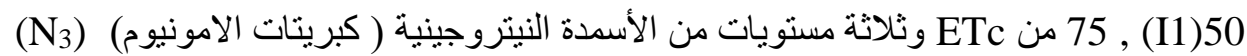

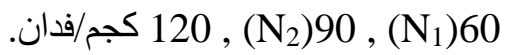
تم قياس نسبة انسداد النقاطات لنظام الري بالتنقيط عند بداية ونهاية موسم نمو الثوم $r . V / r \ldots T$ J تبعاً لنسبة الإنسداد فإن أنظمة الحقن المستخدمة تم ترنيبها ترنتياً تصاعدياً >

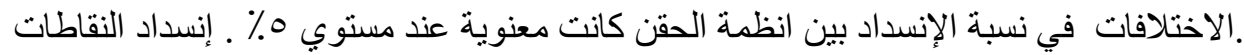
ازدادت بزيادة معدل إضافة النبتروجين و انخفاض معدل الري فكانت اكبر قيمة و اقل قيمة لنسبة

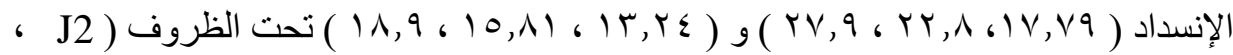
( I $\left.13 \times \mathrm{N}_{1}\right),\left(\mathrm{I}_{1} \times \mathrm{N}_{3}\right)$ ، ( J3 ، J1

1 ـ قسم الهندسة الزر اعية، كلية الزر اعة، جامعة عين شمس. 2 - قسم العلاقات المائية والري الحقلي، المركز القومي للبحوث 